\title{
Central nervous regulation of the hypothalamic-pituitary-adrenal axis and its impact on fertility, immunity, metabolism and animal welfare - a review
}

\begin{abstract}
Summary
The paper reviews mechanisms of neuronal control of the hypothalamic-pituitary-adrenal (HPA) axis with a view on its impact on performance and welfare. The limbic hippocampal and amygdaloid input to the paraventricular hypothalamic nucleus constitutes the basic intracerebral axis by which emotional stimuli affect the stress response. This axis is the backbone of the HPA feedback loop where hippocampus and amygdala are plastic elements and add the ability of experience dependent adaptation and (emotional) learning. As a result large individual differences of the stress response may occur. The system mutually interacts with the immune system and with hypothalamic cell groups which control metabolism and fertility, explaining the influence of stress on these performance parameters. It is concluded that for the reliable assessment of emotional welfare in (farm-) animals a multitude of physiological and behavioral measures are needed which take into account the highly crosslinked nature of the system.
\end{abstract}

Key Words: HPA axis, regulation, brain, performance, animal welfare

\section{Zusammenfassung}

Titel der Arbeit: Zentralnervöse Regulation der Hypothalamus-Hypophysen-Nebennierenrindenachse und ihr Einfluss auf Fruchtbarkeit, Immunstatus, Metabolismus und Wohlbefinden - eine Übersicht

Es werden Mechanismen der neuronalen Kontrolle der Hypothalamus-Hypophysen-Nebennierenrinden- (HPA-) Achse beschrieben und ihre Einflüsse auf Leistungs- und Befindlichkeitsparameter beleuchtet. Die limbischen Hirnzentren Hippocampus und Amygdala bilden mit ihren Signalen zum paraventrikulären hypothalamischen Nukleus das Rückgrat der intrazerebralen Achse, über die psychische Reize die Stressantwort steuern. Hippocampus und Amygdala sind dabei plastische Elemente, die erfahrungsabhängig physiologische und Verhaltensanpassungen (Lernen) beeinflussen. Als Ergebnis können große individuelle Unterschiede der Stressantwort auftreten. Das System interagiert mit dem Immunsystem und hypothalamischen Neuronenverbänden, die den Metabolismus und die Fruchtbarkeit steuern, wodurch die Wirkung von Stress auf diese Leistungsparameter erklärt werden kann. Die Eigenschaften des Gesamtsystems führen zu der Schlussfolgerung, dass für die zuverlässige Einschätzung des psychisch-emotionalen Wohlbefindens bei (Nutz-) Tieren mehrere physiologische und Verhaltensparameter benötigt werden, die die hochgradig vernetzte Regulation berücksichtigen.

Schlüsselwörter: HPA-Achse, Regulation, Gehirn, Leistung, Wohlbefinden

\section{Biological function of HPA activity in stress}

The aim of this paper is to give the reader an overview of the current understanding of the complex regulation of the hypothalamic-pituitary-adrenal (HPA) axis with its impact on health, fertility, metabolism, and behavioral adaptation. This is, obviously, of particular interest in farm animals where performance and welfare are considerably interfering with (emotional) stress and the resulting coping attempts.

Every environment where animals live is to some degree unpredictable. Although some aspects may be quite regular and can be anticipated, like places of feed supply, 
the presence of conspecifics or neutral species, the light-dark cycle and so forth, there is also a number of events which may occur unexpectedly. Basically, the strategy of all animals is to predict as many situations as possible and to acquire strategies to cope successfully with them. Some of these strategies may have been developed during phylogeny and, hence, are innate to a species. More or less stereotyped innate behavioral reactions can be found in many so called lower vertebrates but also in many birds, for example chickens which try to hide when a large dark object is seen above them. Also in mammals innate behaviors exist which are provided to eliminate internal (i.e. neuronal, hormonal or nutritional) or external (environmental) disturbances of equilibrium. Any instinctive behavior, as for example in the context of hatching or mating but also following injuries or physical restraint can be understood as being of that type. Learning is the ability of acquiring appropriate actions to challenges where no a priori strategy to cope with exists. As a result new skills emerge which can appropriately be applied later on in similar situations. If skills, learned or innate, are completely suitable to an actual problem, carried out effortlessly and largely automatised the animal appears calm and undisturbed during the performance.

In more general terms: any individual tries to gain control over an initially uncontrolled situation. Thus, a loss of immediate control (may it be over environmental events or over the own body and its perception) is stressing and requires to be abolished. The respective reaction always starts with an increased state of vigilance and the activation of energy stores. This first alert phase of the stress response follows the appearence of an unpredicted situation, or a situation where formerly successfully applied skills do no longer work, or a situation which is known to require activity.

When an animal is confronted with a stressful event there may be cases where coping cannot be finished within a short period. Such situations may occur when prolonged efforts have to be made because the stressor is resistant. In some cases successful measures to cope with them have to be found in a more or less long lasting process applying a trial and error strategy. The contexts of such stressful distracting events and the behavioral strategies which have eventually been able to get rid of them should be learnt in order to be more quickly successful in the next instance. In addition, physiological reactions are necessary that set the body in a state of endurance for a prolonged coping process.

In the light of this it is evident that an active organism must have an equipment that enables it to i) react quickly and immediately to stressors and ii) augments the plasticity of relevant structures in the central nervous system, attenuates non-vital physiological processes and decreases pain perception in order to improve the chance of survival. In vertebrates, the first phase is immediately initiated by the instantaneous activation of the sympathico-adrenomedullary (SAM) system upon the arising event (Fight-Flight-Response). Physiological effects are increases in blood pressure and heart rate, and in the level of circulating glucose as a result of an augmented adrenaline release by the adrenal medulla, and, in addition, the generation of a high level of vigilance, mediated by noradrenaline (JANSEN et al., 1995). The second phase starts with a short delay (typically one to a few minutes) after the onset of the stressor (PALKOVITS, 1987) with the activation of the HPA axis and the release of its endocrine glucocorticoid hormone which is cortisol in most, but not all, vertebrates. 
Depending on the activity of the HPA system the ability for learning, immunological responses, food intake and the katabolic-anabolic equilibrium, as well as behavior, fertility and sexual libido can be influenced complexly. SELYE's $(1936,1946)$ original stress concept assumed a general, non-specific adaptation including the activation of the HPA axis. However, it is now becoming evident that reactions to homeostatic and infectious stressors are able to bypass cognitive evaluation whereas emotional stimuli include the activation of higher forebrain centers (HERMAN and CULLINAN, 1997). This activation is thought to mediate the capacity for enduring negative emotional stimuli (KOOLHAAS et al., 1993). Consequently, in the context of animal welfare the psychological aspect of stress has gained major notice (v. BORELL, 2000).

Several feedback loops within the central nervous system regulate the activity of the HPA axis. They ensure the maintenance of stable glucocorticoid levels while they provide an emergency override in the brain in order to respond to perceived stressors. The central releasers and feedback loops of HPA activity further interact with other hormone control systems which may eventually lead to the side effects of chronic stress.

\section{Neural feedback control of the HPA activity}

For obvious technical and methodological reasons thorough hodological and neurophysiological studies have only rarely been performed in farm animals. Therefore, most of our knowledge of the neuronal system controlling endocrine reactions is based on rodents and has to be considered for extrapolation on farm animals with care.

A basic feature of the HPA axis is its pronounced nyctohemeral cycle consisting of a pulsatile (ultradian) and 24-h rhythmic (circadian) output (WEITZMAN et al., 1971). Pituitary ACTH release is driven by neuronal pacemakers in the hypothalamic paraventricular nucleus (PVN, Fig. 1) whose small celled subdivision gives rise to corticotropin releasing hormone (CRH) and vasopressin (VP) signals to the pituitary portal circulation (WHITNALL, 1993) whereas axons from the large celled part of the PVN project to the neurohypophysis to release VP and oxytocin (for review see AGUILERA, 1998). While CRH seems to be active mainly in the acute phase of stress (BONAZ and RIVEST, 1998) VP is proposed to maintain HPA axis activity after repeated stimulation (LIGHTMAN, 1994).

The PVN is driven by various brainstem, thalamic and forebrain structures (HERMAN and CULLINAN, 1997; DAYAS et al., 2001; MEDINA et al., 2002). Catecholaminerigic pathways from the brainstem directly contact PVN neurons and seem to promote HPA responses to mainly physical stress and immune challenges. Further ascending inputs to the PVN originate from the raphé nucleus and the locus coeruleus, the former conveying serotoninergic, the latter noradrenergic signals. Both, however, have only sparse projections to the PVN but predominantly to forebrain centers, including the limbic system. In this context it may be interesting to note that noradrenaline has been seen involved with active behavioral stress coping (JORGENSEN et al., 1985; STODDARD et al., 1986; DE BOER et al., 1990) requiring higher motor and memory centers. This correlates well with the proposed general arousal function of the noradrenergic locus coeruleus (SVENSON, 1992).

Psychogenic stress exerts its excitatory influence on the PVN by activation of the amygdaloid complex (Fig. 1). The prevailing view is that sensory inputs, relayed at 
thalamic and higher forebrain levels, reach the lateral and central amygdala. The latter give rise to efferents to various downstream centers (DAVIS, 1994). For example, outputs relaying in the lateral thalamus mediate blood pressure reactions while those to the periaqueductal grey are involved in the control of behavioral aspects of stress, including vocalisation. Amygdala induced HPA axis activation is triggered by CRH, which is released by a pathway via the bed nucleus of the stria terminalis (BNST) to the PVN.

One of the major structures which interacts with the amygdala is the hippocampus (Fig. 1). Besides the PVN itself, it belongs to the brain centers with the highest density of glucocorticoid receptors (MEYER et al., 1998; MATTHEWS, 1998). These receptors, constituting two types, the high-affinity mineralocorticoid receptor (MR, type I) and the low-affinity glucocorticoid receptor (GR, type II), are considered to be the main elements of glucocorticoid feedback regulation in the brain. Since solely free glucocorticoids are able to cross the blood-brain barrier their amount determines the strength of the feedback. Occupied cytosolic MR and GR receptors are effective via a slow genomic mechanism (ZAKON, 1998; KARST et al., 2000) and their action on neurons is modulatory rather than excitatory or inhibitory. Hence it was found that, under resting conditions, corticosteroids do not markedly alter neuronal electric activity. However, if the neurons are activated by the action of nerotransmitter input, c.f. from higher cognitive centers or the amygdala, the effect of glucocorticoid modulation becomes apparent. Whereas occupied MRs generally maintain steady electrical activity brief activation of GRs leads to an influx of calcium which may slowly reverse temporally raised electrical activity in the hippocampus. The net effects become apparent after at least an hour but then may last for hours. (JOELS, 2000; 2001).

The hippocampal network with its glucocorticoid receptive neurons exerts an (direct or indirect) inhibitory input to CRH releasing neurons in the amygdala and PVN. The details of this negative feedback loop are not completely known but a general scheme on the basis of neuroanatomy, stimulation and tracing experiments can be outlined (GRAY, 1993; MAKINO et al., 1994; YOUNG and VAZQUEZ, 1996; PITKÄNEN et al., 1997; WEIDENFELD et al., 1997, AGUILERA, 1998). The central amygdaloid nucleus (CA) projects directly and via the BNST to the PVN. Besides in the PVN, $\mathrm{CRH}$-containing neurons can be found in considerable number in the CA and the BNST. As well, CRH-receptors (CRHR) are found in neurons of these structures, in part on those which are themselves $\mathrm{CRH}$-containing, indicating the capability of autoregulation. The hippocampus exerts its inhibitory drive on the PVN likely via inhibitory interneurons. In parallel, hippocampal inputs reach the (baso-) lateral amygadal (BLA) where they may converge with inputs from non-limbic higher sensory centers. Besides in the hippocampus, glucocorticoid receptors are present the CA and the PVN. The occupation of GRs was found to attenuate the effect of electrical activation of CA cells and hypophysal ACTH release whereas the activation of CRHreceptors increase the activity of PVN CRH-neurons and of the ACTH secretion in the anterior pituitary. This suggests a positive CRH-CRHR and a negative glucocorticoidGR feedback. The simple negative feedback-model, however, was challenged by VAN HAARST et al. (1997). Based on their results that, at the diurnal corticosteroid peak in rats, intracerebroventricular applied corticosteroid antagonists increased while hippocampal injections decreased ACTH release, they suggested a negative feedback 
via hypothalamic GRs and a positive feedback by the hippocampal GRs. This would be consistent with a model where excitatory hippocampal outputs contact inhibitory interneurons of the PVN and projection neurons as well as inhibitory interneurons in the amygdala. Depending on the specific stressor and amygdaloid microcircuits shaped by individual experience the hippocampus may more effectively inhibit or excite the CRH-response from the CA.

It should be mentioned that also in the nucleus coeruleus CRHR can be found so that the immediate noradrenergic stress response could be further enhanced by this structure projecting to the CA and the PVN. It is evident that treatment, species and / or individual variations of the gains and the time constants in these feedback loops may acount for different responses to acute or chronic psychological stress found in many studies on the reactivity of the HPA axis (DESAUTES et al., 1999; KANITZ et al., 1999; PERREAU et al., 1999; LADEWIG, 2000; OTTEN et al., 2001; 2002). Individual- and species-specific transitions between permissive, suppressive, stimulatory and preparative states define the basal level, the overshoot prevention and the rebound release of a prolonged stress response with its long term consequences (SAPOLSKY et al., 2000).

Chronically elevated glucocorticoid levels in rodents, pigs and likely also in humans are able to modify the concentration of their intracellular receptors in elements of the feedback loop, especially in the hippocampus (SUTANO et al., 1996; VÁZQUEZ et al., 1996; KANITZ et al., 1998; BUWALDA et al., 2001; WELBERG and SECKL, 2001). Such elevated levels may result from chronic stress or regulative disorders and they are able to down-regulate MRs and GRs in the hippocampus and in the hypothalamus. Up- or down-regulations of receptors are thought to be indicative of low or high amounts of available glucocorticoid. Regulation helps to maintain homeostasis, as fewer receptors, which are almost all occupied, should result in a similar neuronal output as many receptors, which are occupied only in part but are able to catch any available glucocorticoid molecule. Thus, up-regulation increases feedback sensitivity while glucocorticoid levels are low, whereas down-regulated receptors decrease sensitivity. A complete and sustained lack of glucocorticoids, however, results also in downregulation of GRs in rats, since in adrenalectomized animals a marked decrease of brain GR-mRNA and the disappearance of GR-immunoreactivity have been found (HU et al., 1997). The regulation of intracellular glucocorticoid receptors is apparently mediated by an interaction of the receptor with the $70 \mathrm{kDa}$ heat shock protein (HSP70) and with the receptor-associating protein 46 (RAP46) that regulates the transactivation function of several steroid receptors (SCHNEIKERT et al., 2000).

Also the circadian and pulsatile rhythm of the HPA axis, besides being synchronized by optic inputs via the suprachiasmatic nucleus (ASCHOFF, 1984; SAGE et al., 2002) is likely to be controlled by the properties of the multiple feedback loops in the brain and basicly influenced by MRs while GR-effects tune the peak activity (REUL et al., 1987). The importance of the glucocorticoid feedback for the generation of rythmical HPA dynamics was demonstrated in humans in an experimental low-feedback paradigm which resulted in reduced amplitude of nyctohemeral cortisol rhythm by $45 \%$ and a $7.1 \mathrm{~h}$ delay of the cortisol maximum (acrophase). The effect on ACTH secretion was an 12-fold amplification of the secretory burst mass, yielding a higher percentage of pulsatile ACTH with only minor effects on the nonpulsatile ACTH 
secretion, burst frequency, and burst duration. In addition, the ACTH pulses occurred more regularly, indicating a chaotic influence of the intact feedback on pulsatile ACTH secretion (VELDHUIS et al., 2001). Accordingly it can be demonstrated in mathematical simulations that the complex cortisol feedback inhibition of CRH/VP and ACTH production via time-delayed concentration-dependent and rate-sensitive mechanisms is able to mediate the dynamic homeostatis of the HPA axis by nonlinear and time-delayed signal interchanges (KEENAN et al., 2001).

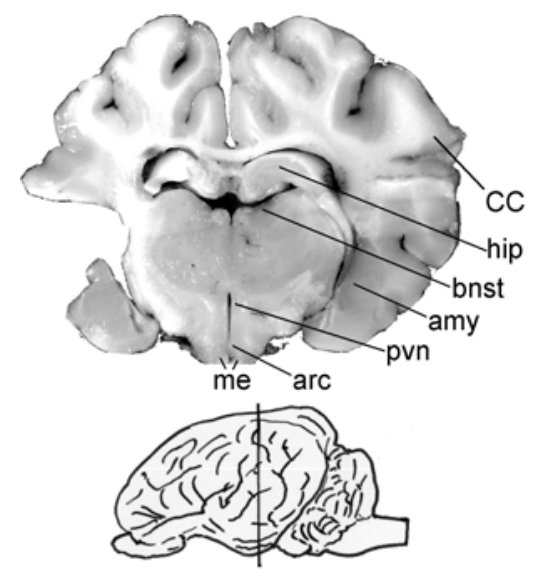

Fig. 1: Frontal section through a pig brain at the level indicated below. It includes some major elements of central regulation of HPA and HPG axis. amy: amygdala; arc: N. arcuatus; bnst: bed nucleus of stria terminalis; hip: hippocampus; me: median eminence; pvn: paraventricular nucleus of hypothalamus (Frontalschnitt durch das Gehirn eines Schweines an der unten skizzierten Stelle. Die Schnittebene enthält wichtige Elemente für die Regulation der HPA- und HPG-Achsen. amy: Amygdala; arc: Nucleus arcuatus; bnst: Bed nucleus der Stria terminalis; hip: Hippocampus; me: Eminentia medialis; pvn: Nucleus paraventricularis hypothalami)

\section{Regulatory and modulatory effects of HPA-axis activation on fertility, metabolism, immunity, and behavior}

It is beyond the scope of this paper to review in detail the large amount of research on the complex relationships and modulatory influences of the HPA axis upon the control of various endocrine, immunological and behavioral regulations. Instead, the intention is to supply a rough overview of the main elements and sites of interaction in order to give an impression of a network that to date is still far from being completely understood.

$\mathrm{CRH}$ is the main intracerebral messenger of the HPA axis and triggers the synthesis of ACTH and $\beta$-endorphine from proopiomelanocortin (POMC) in the arcuate nucleus of the hypothalamus and the nucleus of the solitary tract as well as in the anterior pituitary (RIVIER and RIVEST, 1991). Therefore, the interaction of this neurohormonal system with networks regulating reproduction, metabolism, immunity, and (learning-) behavior will be in the center of interest.

\section{Fertility}

The negative influence of stress on female reproduction system has been known for a long time in humans and animals (BROADHURST, 1960, MOBERG, 1980; ADAMS et al., 1985; DOBSON and SMITH, 2000). To a lesser extent a similar situation may also exist in males (COLLU et al., 1984; RABIN et al., 1988; RIVIER and RIVEST, 
1991). An attenuated release of luteinizing hormone (LH) resulting from sustained stress has consistently been observed.

Although opioids may play a major role in stress mediated modulation of fertility (SYLVESTER et al., 1982; GOODMAN et al., 1995; OKRASA and KALAMARZ, 1996), particularly in males an inhibitory effect of glucocorticoids on testicular function has been found in vivo and in vitro (BAMBINO and HSUEH, 1981; WELSH et al., 1982). However, continuously elevated levels of glucocorticoids may also adversely influence the activity of the hypothalamo-pituitary-gonadal (HPG) axis in human females (YEN, 1986). A similar result in sheep has been gained recently demonstrating that continuously administered cortisol impairs follicular development (MACFARLANE et al., 2000).

Neurons that contain gonadotropin-releasing hormone (GnRH) are scattered throughout the hypothalamus with, in the rat, highest density in the medial preoptic area (MPOA) and the median eminence (ME, Fig. 1) whose neurons give rise to terminals at pituitary portal blood vessels (THIÉRY and MARTIN, 1991). GnRH from the $\mathrm{ME}$ then signals the release of luteinizing hormone $(\mathrm{LH})$ from the pituitary. In various studies $\mathrm{CRH}$ has been found to inhibit this release by direct or indirect action (for review see RIVIER and RIVEST, 1991; RIVEST and RIVIER, 1993; CHROUSOS et al., 1998). Contrary to the inhibition by the HPA axis, noradrenergic input dose dependently stimulates GnRH secretion (PARVIZI and ELLENDORFF, 1982). The effect is complex and may involve several neuronal dopaminergic systems which may mutually augment or attenuate each other (THIÉRY and MARTIN, 1991; HERBISON, 1997). This may in part explain the transient LH raise sometimes measured in acute stress situations. However, this beneficial effect is abolished by sustained stress when HPA activity overrides.

The MPOA receives direct CRH nerve terminals from the PVN and the CA, and CRH inhibits MPOA GnRH neurons as well as $\mathrm{ME} \mathrm{GnRH}$ release so that these hypothalamic sites appear to be major centers for the interaction of the HPA axis with the central controlers of the reproductive system (Fig. 2). Besides direct CRH inhibition a $\beta$-endorphine mediated attenuation of $\mathrm{GnRH}$ release is observed which mainly originates from the arcuate nucleus (Fig. 1) that projects to the ME and the MPOA and in turn receives excitatory $\mathrm{CRH}$ input. In addition, sustained excessive glucocorticoid levels may affect LH secretion by direct pituitary action (SAKAKURA et al., 1975). The negative net effect of CRH on fertility may be the main reason for fertility impairments often observed coincidently with poor welfare.

\section{Metabolism}

Similar relationships exist between the HPA axis and metabolic control (Fig. 2). Corticosteroids exert dose dependent effects on food intake and energy expenditure. At lower doses they stimulate food intake (DEVENPORT et al., 1989) which may result in obesity. Hence, maladaptation to chronic stress has been claimed to be a reason for hyperphagia and obesity in humans (BJORNTORP, 1991). At high pharmacological doses, however, corticosteroids decrease food intake and body weight. This correlates with the induction of the leptin $(o b)$ gene in the fat tissue (DE VOS et al., 1995; SLIEKER et al., 1996).

The adipocyte-derived katabolic peptide hormone leptin interacts with the HPA (as well as with the HPG) axis (LICINIO et al., 1997). CRH plays a central role in food 
intake and energy homeostasis and is a mediator of the catabolic effect of leptin (UEHARA et al., 1998). Accordingly, CRH administered directly to the brain reduces food intake in various mammals, including sheep (RUCKEBUSCH and MALBERT, 1986) and, vice versa, leptin stimulates the HPA axis. There are also dependences of leptin secretion on parturition states and infections, and central mechanisms may in part also be responsible for these effects (INGVARTSEN and BOISCLAIR, 2001).

Receptors for leptin are expressed by neurons in the hypothalamic arcuate nucleus that project to the PVN (SCHWARTZ et al., 2000). Leptin may suppress the HPA axis by an ihibition of CRH and adrenocortical glucocorticoid secretion (HEIMAN et al., 1997; BORNSTEIN et al., 1997) but contradictory results have been reported (INUI, 1999) which indicates a complex and probably species dependent interaction, and in fact there are some species differences in the secretion mode and effects of leptin. While rodents and humans display diurnal changes in leptin secretion this has not been observed in sheep, and leptin deficiency in rodents, but not in humans, results in hypothermia, hyperinsulinaemia, and hypercorticism (VERNON et al., 2001). In the ewe, leptin does not affect normal insulin, glucose and cortisol levels and increases plasma lactate and nonesterified fatty acids. This indicates a state of negative energy balance where leptin induced low feed intake is not accompanied by endocrine effects (HENRY et al., 1999).

Neuropeptide Y (NPY) is an opponent of leptin and is likely to stimulate CRH release by the PVN. In the arcuate nucleus of rats and sheep leptin and NPY are colocalized (HAKANSSON et al., 1998; WILLIAMS et al., 1999). NPY-neurons in the arcuate nucleus are inhibited by CRH and leptin and modulated by $\beta$-endorphine and serotonine (for review see KRYSIAK at al., 1999; INUI, 2001). In rat, glucocorticoid is required for NPY to increase food intake and may produce obesity symptoms (JEANRENAUD and ROHNER-JEANRENAUD, 2000), an effect probably elicited by decreased CRH as a result of augmented negative feedback.

It has been found in addition that NPY in the amygdala is able to reduce experimentally induced anxiety in the rat (HEILIG et al., 1994) and that amygdala intrinsic NPY neurons display decreased NPY mRNA levels after restraint stress (THORSELL at al., 1998). Hence, NPY may override fear in a hungry animal.

\section{Immunity}

There is now overwhelming evidence that mental stress may be detrimental to health and the resistance to infections in man and animals. Although the experimental results are not completely uniform (for review see MCEWEN et al., 1997) it appears that chronic uncontrollable stress is most hazardous to immunity whereas efforts which eventually result in successful coping may be immune-supporting (TUCHSCHERER et al., 1998; PETERS et al., 1999).

To a large deal, though not exclusively, immune ractions to stress are due to the modulating function of the HPA axis (MCEWEN et al., 1997; OLFF, 1999; PETERS et al., 1999; TUCHSCHERER and MANTEUFFEL, 2000). Adrenal steroids exert major influence on the cytokine production. They inhibit various types of interleukines and tumor necrosis factor (TNF). Further, IL-2 driven proliferation of lymphocytes is inhibited, probably by an inhibition of the respective receptor (BATUMAN et al., 1994). Glucocorticoids are further able to supress antigen specific responses of $T$ lymphocytes in humans (FAUCI and DALE, 1974), and the generation of cytotoxic T 
lymphocytes has been found to be impaired by stress in mice (KUSNECOV et al., 1992) and pigs (KANITZ et al., 2002).

An important task of glucocorticoids is the control of the distribution of leucocytes. They are thought to signal specific immune cells to exit the peripheral blood and enter lymphatic and other tissue. Thus, this redistribution may have significant consequences for the ability of the immune system to perform its surveillance and effector functions (MCEWEN et al., 1997). In accordance with this, stressed animals have shown an increased amount of leucocytes in the skin before and after an antigenic challenge (DHABHAR and MCEWEN, 1996).

Although the precise interactions of glucocorticoids with the immune system are far from being completely understood the situation is even worse with the other major secretagogue of the HPA axis, ACTH (adrenocorticotropic hormone). It seems that the effects of ACTH on immune cells is complexly influenced by various factors, such as its concentration and the presence and amount of cytokines. It may exert direct and indirect effects at several levels, like modulation of signal transduction or influencing the cellular production of growth and differentiation factors (OTTAVIANI et al., 1999).

The immune system acts on and is modulated by the HPA axis via central and peripheral mechanisms (for reviews see JONES and KENNEDY, 1993; KARALIS et al., 1997; MCEWEN et al., 1997). The majority of studies suggest that direct stimulation of hypothalamic CRH by cytokines, such as interleukin (IL-1), tumor necrosis factor (TNF- $\alpha$ ), and interferon (IFN- $\alpha$ ) secreted by macrophages, is the principal route by which immune activation stimulates the HPA axis. However, in chronic inflammatory states, like in chronic stress conditions, the activation of the HPA axis is maintained by increased hypothalamic VP secretions, whereas CRH increase is observed in the initial state of the infectious disease. Peripheral cytokines may reach the central nervous system (CNS) either directly using specific transporters to cross the blood-brain barrier or may trigger intra-CNS cytokine production. After infection cytokines are expressed in much larger quantities than normally within the CNS (CONNOR and LEONARD, 1998).

On CNS-levels cytokines may act via stimulation of the arcuate nucleus and the PVN where high affinity receptors for IL-1 have been detected. Immunoneutralization of these receptors has been found to inhibit the IL-1 stimulated ACTH release from the pituitary (RIVIER et al., 1989). It should also be mentioned that lymphocytes themselves are able to produce ACTH (OTTAVIANI et al., 1999) and CRH (CHROUSOS, 1995). In addition, $\mathrm{CRH}$ is also secreted from terminals of ganglionic sympathetic nerves at inflammatory sites. This secretion is suppressed by glucocorticoids (and somatostatin) which exert a complex, not yet completely disentangled effect on the immune system. Immune cells possess intracytoplasmatic MRs and GRs, the latter being more widespread, c.f. in thymus, spleen and lymph nodes (KUSNECOV and RABIN, 1994), but the mechanism of their action has not clearly been unraveled.

The net effect of $\mathrm{CRH}$ on immune function, however, seems to decrease cellular immunity, including the secretion of IFN- $\alpha$, while antibody mediated humoral immunity remains largely unaffected. Accordingly, intracerebroventricular $\mathrm{CRH}$ injections in pigs revealed lower activity of natural killer cells, a low neutrophil chemotaxis and a lower percentage of plasma lymphocytes (SALAK-JOHNSON et al., 
1997), as was similarly found in pigs subjected to social stress (TUCHSCHERER et al., 1998).

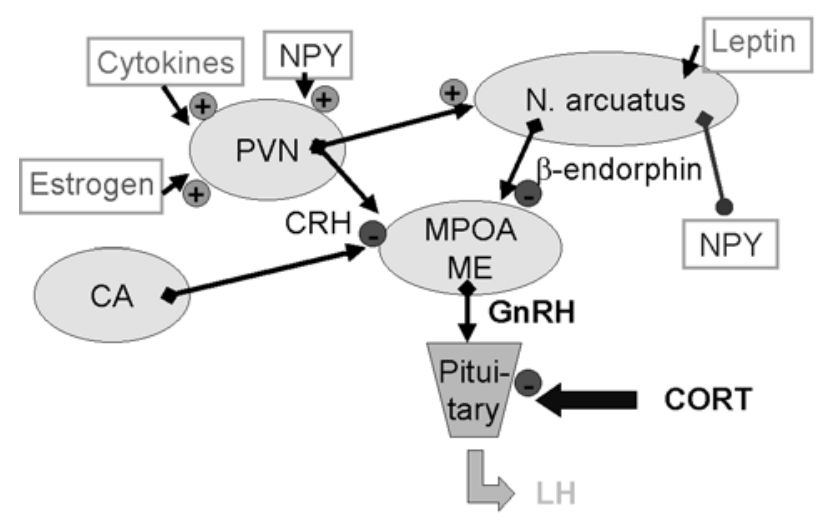

Fig. 2: Basic layout of the interactions of the stress axis (PVN: paraventricular nucleus, CA: central amygdala, CORT: glucocorticoid) with gonadal and metabolic control (Vereinfachtes Schema der Interaktionen der Stressachse (PVN: Nucleus paraventricularis hypothalami, CA: Nucleus centralis amygdalae, CORT: Glucocorticoide) mit der gonadischen und metabolischen Regulation)

\section{Behavioral adaptation}

Sustained activation of glucocorticoid receptors in the hippocampus can lead to cellular atrophy and apoptosis (KIM and YOON, 1998; STARKMAN et al., 1999) which may, among other reasons, be the result of an overshooting calcium influx caused by chronically activated glucocorticoid and glutamate receptors. This may lead to an impairment of declarative (rule-) learning during high levels of chronic stress. Moderate and transient stress, however, may be beneficial to learning, an effect that may involve, besides more general arousal functions of noradrenergic inputs, $\mathrm{CRH}$ receptors in the hippocampus which have been found to enhance long-termpotentiation of synaptic efficacy (WANG et al., 1998). Apparently, an important hippocampal CRH source is the amygdala, which has been demonstrated to exert a biphasic (immediate excitatory and long lasting inhibitory) influence on hippocampal plasticity and hence may be the central link between stress and declarative learning (AKIRAV and RICHTER-LEVIN, 1999; KIM and DIAMOND, 2002). In farm animals this type of learning occurs during adaptation to structures of keeping facilities, milking regimes etc. and may be prone to be affected by stress.

Emotional learning has been intensively investigated in the rat (for review see KORTE, 2001). However, it can at least be argued to what extent data from this animal can be extrapolated to, for example, large farm animals where typical reactions of rats, like freezing or acoustic startle responses are virtually absent or considerably less expressed. In contrast to declarative memory acquisition where the hippocampus is a major element, emotional behaviors (unconditioned fear, anxiety behaviors) and their modifications by experience (conditioned fear responses) are largely based on the amygdala and its own plasticity (DAVIS, 1994). In humans, electrical stimulation of the amygdala during neurosurgery mainly elicits feelings of fear or apprehension supporting the data from animal experiments. Hence, the sets of largely innate behaviors and physiological reactions which are contingent on negative emotions probably result from amygdaloid activation which is then transferred to neuronal downstream targets being responsible for the observed symptomatic phenomenons. In 
the course of life experience specific or contextual information from higher sensory and cognitive centers may enter the amygdaloid neuronal network and change its properties which may finally lead to the activation of the innate set of physiological and behavioral reactions, now released by learnt stimuli.

Since amygdaloid neurons possess glucocorticoid receptors and are modulated by hippocampal input it is not surprising that glucocorticoids influence emotional behavior and learning. Roughly, the experimental results indicate a permissive role of MRs in the expression of existing stimulus-response chains at low and intermediate levels of glucocorticoids, whereas GRs fascilitate emotional conditioning at higher stress levels (KORTE, 2001). Hence, the hippocampus may act as a brain center that compares existing knowledge on stress-coping with the actual situation. If coping strategies exist and work well glucocorticoid levels remain moderate. If, however, coping is unsuccessful the stress level raises and fascilitates searching for and storing of new behavioral solutions. It might be hypothetized, therefore, that mainly hippocampal MRs influence the inhibitory input to the PVN, thus maintaining the basal equilibrium of HPA activity in normal and low-stress situations while the excitatory and modulatory hippocampal efferents to the amygdala supporting emotional learning are GR dominated.

While glucocorticoids have no direct effect on behavior, CRH applied to the brain in pigs resulted in an increased overall motor activity and vocalisation (SALAKJOHNSON et al., 1997), as it has been found similarly in rats (DUNN and BERRIDGE, 1990; KOOB et al., 1993). A decrement of open field behavior was observed after CRH administration into the amygdala (LIANG and LEE, 1988) and into the locus coeruleus (BUTLER et al., 1990), where electrical activity and, probably as a result, attentive arousal was enhanced with CRH input (VALENTINO et al., 1993).

Behavioral stereotypies are maladaptions that may occur as a result of long lasting unescapable stressful, boring and movement restricted conditions. They frequently express themselves as perpetuated gnawing or chewing, continuous grooming, or circling. There is evidence that in some mammals a low HPA reactivity correlates with a greater tendency to develop stereotypic behaviors (REDBO, 1998; POL et al., 2002). In a study with horses, however, a positive correlation between stereotypic crib-biting and cortisol baseline levels was found (MC GREEVY and NICOL, 1998) and in fowl there was hardly a correlation at all (SAVORYA and MANNA, 1997). Taken together, these results point to a complex and species dependent interplay between HPA-axis activity and the sensitivity to opioids (LADEWIG et al., 1993).

It has been suggested that stereotypies occur in response to high levels of arousal and sympathetic drive, as indicated by sometimes elevated heart rates in stereotyping animals. However, it is more likely that endogenous opiates are critically involved in the generation of stereotypies, as the opiod antagonist nalaxone is able to reduce stereotypic behavior (SCHOUTEN et al., 1991), and in various animals as well as in human individuals opiates are able to elicit stereotype-like behaviors (KATZ et al., 1978; OLIVERIO et al., 1984; ISAACSON and GISPEN, 1990). In elder sows, however, naloxone did not exert large effects on stereotypies, which may indicate more "automatized" behavior (SCHOUTEN, 2000).

The facilitating effect of opioids (particularly $\beta$-endorphine with its high affinity to $\mu$ and $\delta$-opioid receptors) on stereotypic behavior may be mediated via the mesolimbic 
dopaminergic pathway from the ventral tegmental area (VTA) to the nucleus accumbens (Nac) (CABIB, 1993). In the Nac, dopamine is increased by stress in its shell subdivision (DEUTCH and CAMERON, 1992). It has been found, accordingly, that amphetamines, cocaine, and $\mathrm{CRH}$ in the Nac increase stereotypic behavior (LIENAU and KUSCHINSKY, 1997; HOLAHAN et al., 1997). In the light of these results the development of stress induced stereotypies and the glucocorticoid response may each be due to the activation of different CNS systems, the arcuate nucleus-VTAaccumbal axis and the classical HPA axis, respectively. Both may be triggered by CRH but may act more or less independently (Fig. 3).

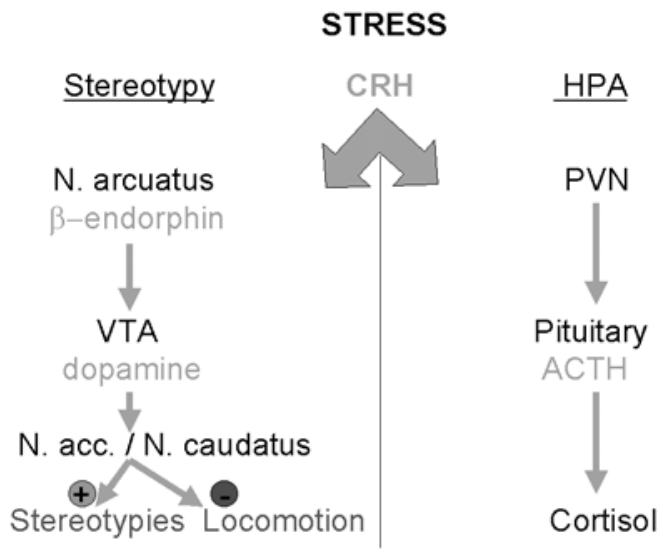

Fig. 3: The two pathways by which emotional stress may release stereotypic behaviour and / or HPA axis activation (Zwei Wege, über die emotionaler Stress stereotypes Verhalten und / oder HPA-Achsenaktivierung auslösen kann)

\section{HPA axis and animal welfare}

If a prolonged activation of the HPA-axis by chronic stress has several negative effects, what may be the positive biologically adaptive aspect of this endocrine system? The answer becomes evident when the important role of glucocorticoids in the maintenance of homeostasis is mentioned. Glucocorticoids protect the body against overshooting immune reactions which may severely damage tissues and thus may be hazardous to individual survival (MUNCK and GUYRE, 1991). Accordingly, neutralization of endogenous glucocorticoid function results in enhanced pathology and mortality in animals exposed to endotoxins, and similar enhanced pathological effects have been found to occur after viral infections in the absence of an active HPA axis (for review see MILLER, 1998). If a transient stress exposure is considered, in the course of agonistic conflicts for example, the distributing action of glucocorticoids serving immune cells to be at the right places (e.g. skin or peripheral lymph nodes) is certainly another highly adaptive feature.

The facilitation of emotional learning by glucocorticoids is surely adaptive as well in the (transient) stress response. In its best form it may ensure single shock learning of relevant relations during an impressive emotional event (e.g. an electric fence). As a result these relations are readily present in later similar situations and can be used for successful problem solving and the control of future stressful events.

Altogether, in non-stress conditions the HPA axis serves the maintenance of general homeostasis (JOHNSON et al., 1992) by accomplishing the functions of other hormones, as for example insulin and adrenaline, and regulates the metabolism of 
proteins, carbohydrates, and fats (DÖCKE, 1994). In stress situations, however, HPA axis activity is able to inhibit biologically costly behaviors and vegetative functions, such as reproduction, feeding and growth.

Regarding the assessment of animal welfare, especially in non-laboratory housings like farm keeping, the greatest difficulties may arise when psychological stress has to be judged (MANTEUFFEL and PUPPE, 1997). Physical stress and diseases are much more overt for evaluation than mental feelings hidden in the central nervous system. It is for that reason that activity of the HPA axis has received much effort to be interpreted in terms of psychological stress. Cortisol can be measured by non-invasive methods (saliva: COOK et al., 1996; SCHÖNREITER and ZANELLA, 2000; urine: HAY and MORMÈDE, 1997), hence, it may be an ideal substrate for measuring stress in farm animals. But how is HPA activity and cortisol correlated to emotional stress perception? Transient, not regularly repeated, short stress and resulting transient responses of the HPA axis during anticipation and coping may not really affect welfare but rather may be a suitable way to overcome boredom, as for example during mating (BORG et al., 1991). However, chronically sustained or repeated stress not only affects welfare but also fertlity and, by way of negative effects on the immune system, susceptibility for infections and related diseases. Is this clearly indicated by measures of HPA activity, particularly cortisol? This may be, but with some restrictions. First of all and fundamentally, in order to reduce variations between the measurements nyctohemeral secretions of the HPA axis have to be determined at the minimum or the maximum of the daily rhythm when slight phase shifts between individuals or short delays between the single measurements result only in minor effects on the determined amount of the substance since the intrinsic dynamic variations are small at these points. Further, the HPA response does not only depend on the stressor but also on species- and breed-specific genetic traits and individual experience. Individuality in the stress response, including the HPA axis, must not be underestimated and becomes clearly evident when the important role of the highly modifiable neuronal networks in the amygdala and hippocampus are considered which are crucially involved in the mediation of stress. Accordingly, variations in HPA stress responses depending on individual fate including the prenatal phase have been demonstrated in various species (ROSENBLUM, 1987; WELBERG et al., 2000; WELBERG and SECKL, 2001; OTTEN et al., 2001; TUCHSCHERER et al., 2002) and may result in large individual differences.

For this reason, a multidimensional vector of measures has been demanded as being neccessary for the assessment of stress and welfare (BROOM, 1991; RAMOS and MORMÈDE, 1998; MANTEUFFEL and PUPPE, 2000). This should include as many as possible $\mathrm{CRH}$-induced components from the behavioral, endocrine and immune domains, as well as fertility and diseases. Particularly regarding farm animals in their commercial housings opiate-mediated behaviors like apathy and stereotypies may be observed and behaviorally and physiologically quantified (ZANELLA et al., 1996), cortisol can be determined noninvasively, forms of diseases resulting from weak immune responses can be assessed routinely and vocalisations can be registrated automatically (SCHÖN et al., 2001). However, before such measures can be applied in commercial housings they have to be calibrated, cross-calibrated and validated in defined and well-controlled situations in order to secure their value for conclusions on emotional state and welfare disturbances. 


\section{References}

ADAMS, M.R.; KAPLAN, J.R.; KORITNIK, D.R.:

Psychosocial influences on ovarian endocrine and ovulatory function in Macaca facicularis. Physiol. Behav., 35 (1985), 935-940

AGUILERA, G.:

Corticotropin releasing hormone, receptor regulation and the stress response. Trends Endocrinol. Metabol., 9 (1998), 329-336

AKIRAV, R.L.; RICHTER-LEVIN, G.:

Biphasic modulation of hippocampal plasticity by behavioral stress and basolateral amygdalar stimulation in the rat. J. Neursosci., 19 (1999), 10530-10535

ASCHOFF, J.:

Circadian timing. Ann. N.Y. Acad. Sci., 423 (1984), 442-468

BAMBINO, T.H.; HSUEH, A.J.W.:

Direct inhibitory effect of glucocorticoids upon testicular luteinizing hormone receptor and steroidogenesis in vivo and in vitro. Endocrinology, 108 (1981), 2142-2148

BATUMAN, O.A.; FERRERO, A.P.; DIAZ, A.; BERGER, B.; POMERANTZ, R.J.:

Glucocorticoid-mediated inhibition of interleukin-2 receptor-a and -B subunit expression by human $\mathrm{T}$ cells. Immunopharmacology, 27 (1994), 43-55

BJORNTORP, P.:

Metabolic implications of body fat distribution. Diabetes Care, 14 (1991), 1132-1143

BONAZ, B.; RIVEST, S.:

Effect of chronic stress on CRF neuronal activity and expression of its type 1 receptor in the rat brain. Am. J. Physiol., 44 (1998), 1438-1449

BORG, K.E.; ESBENSHADE, K.L.; JOHNSON, B.H.:

Cortisol, growth hormone, and testosterone concentrations during mating bahavior in the bull and boar. J. Anim. Sci., 69 (1991), 3230-3240

BORNSTEIN, S.R.; UHLMANN, K.; HAIDAN, A.; EHRHART-BORNSTEIN, M.; SCHERBAUM, W.A.: Evidence for a novel peripheral action of leptin as a metabolic signal to the adrenal gland: leptin inhibits cortisol release directly. Diabetes, 46 (1997), 1235-1238

BROADHURST, P.L.:

Experiments in psychogenic applications of biomedical genetics to the inheritance of behavior. In: H.J. EYSENCK (ed.), Experiments in personality psychogenetics and psychopharamcology Vol. 1, pp 1102, ROUTLEDGE and KEEGAN, London 1960

BROOM, D.M.:

Animal welfare: concepts and measurement. J. Anim. Sci., 69 (1991), 4167-4175

BUTLER, P.D.; WEISS, J.M.; STOUT, J.C.; NEMEROFF, C.R.:

Corticotropin-releasing factor produces fear-enhancing and behavioral activating effects following infusion into the locus coeruleus. J. Neurosci., 10 (1990), 176-183

BUWALDA, B.; FELSZEGHY, K.; HORVATH, K.M.; NYKAS, C.; DE BOER, S.F.; BOHUS, B.; KOOLHAAS, J.M.:

Temporal and spatial dynamics of corticosteroid receptor down-regulation in rat brain following social defeat. Physiol. Behav., 72 (2001), 349-354

CABIB, S.:

Neurobiological basis of stereotypies. In: A.B. LAWRENCE, J. RUSHEN (eds.), Stereotypic Animal Behaviour. Fundamentals and Applications to Welfare, pp. 119-145, CAB International, Wallingford 1993

CHROUSOS, G.P.:

The hypothalamic-pituitary-adrenal axis and immune mediated inflammation. N. Engl. J. Med., 332 (1995), 1351-1362

CHROUSOS, G.P.; TORPY, D.J.; GOLD, P.W.:

Interactions between the hypothalamic-pituitary-adrenal axis and female reproductive system: clinical implications. Ann. Int. Medicine, 129 (1998), 229-240

COLLU, R.; GIBB, W.; DUCHARME, J.R.:

Effects of stress on the gonadal function. J. Endocrinol. Invest., 7 (1984), 529-537

CONNOR, T.J.; LEONARD, B.E.:

Depression, stress and immunological activation: the role of cytokines in depressive disorders. Life Sciences, 62 (1998), 583-606

COOK, N.J.; SCHAEFER, A.L.; LEPAGE, P.; MORGAN JONES, S.:

Salivary vs. serum cortisol for the assessment of adrenal activity in swine. Can. J. Anim. Sci., 76 (1996), 329-335

DAVIS, $\mathrm{M}$ : 
The role of the amygdala in emotional learning. Interntl. Rev. Neurobiol., 36 (1994), 225-266

DAYAS, C.V.; BULLER, K.M.; CRANE, J.W.; XU, Y.; DAY, T.A.:

Stressor categorization: acute physical and psychological stressors elicit distinctive recruitment patterns in the amygdala and in the medullary noradrenergic cell groups. Eur. J. Neurosci., 14 (2001), 1143-1152

DE BOER, S.F.; SLANGEN, J.L.; VAN DER GUGTEN, J.:

Plasma catecholamine and corticosterone levels during active and passive shock-prod avoidance behavior in rats: effects of chlordiazepoxide. Physiol. Behav., 47 (1990), 1089-1098

DE VOS, P.; SALADIN, R.; AUWERX, J.; STAELS, B.:

Induction of $o b$ gene expression by corticosteroids is accompanied by body weight loss and reduced food intake. J. Biol. Chem., 270 (1995), 15958-15961

DESAUTES, C.; SARRIEAU, A.; CARITEZ, J.C.; MORMÈDE, P.:

Behavior and pituitary-adrenal function in large white and Meishan pigs. Domest. Anim. Endocrinol., 16 (1999), 193-205

DEUTCH, A.Y.; CAMERON, D.S.:

Pharmacological characterization of dopamine systems in the nucleus accumbens core and shell. Neuroscience, 46 (1992), 49-57

DEVENPORT, L.; KNEHANS, A.; SUNDSTROM, A.; THOMAS, T.:

Corticosterone's dual metabolic actions. Life Sci., 45 (1989), 1389-1396

DHABHAR, F.S.; MCEWEN, B.S.:

Stress-induced enhancement of antigen-specific cell-mediated immunity. J. Immunol., 156 (1996), 2608-2615

DOBSON, H.; SMITH, R.F.:

What is stress, and how does it affect reproduction? Anim. Reproduction Sci., 60-61 (2000), 743-752

DÖCKE, F.:

Veterinärmedizinische Endokrinologie. Gustav Fischer, Jena 1994

DUNN, A.J.; BERRIDGE, C.W.:

Physiological and behavioral responses to corticotropin-releasing factor administration: Is CRF a mediator of anxiety or stress responses? Brain Res. Rev., 15 (1990), 71-100

FAUCI, A.S.; DALE, D.C.:

The effect of in vivo hydrocortiosone on subpopulations of human lymphocytes. J. Clin. Invest., 53 (1974), 240-246

GOODMAN, R.L.; PARFITT, D.B.; EVANS, N.P.; DAHL, G.E.; KARSCH, F.J.:

Endogenous opioid peptides control the ampltude and shape of gonadotropin-releasing hormone pulses in the ewe. Endocrinology, 136 (1995), 2412-2420

GRAY, T.S.:

Amygdaloid CRF pathways. In: Y. TACHÉ, C. RIVIER (eds.), Corticotropin-releasing factor and cytokines: role in the stress response, pp 53-60, New York Academy of Sciences, New York 1993

HAKANSSON, M.L.; BROWN, H.; GHILARDI, N.; SKODA, R.C.; MEISTER, B.:

Leptin receptor immunoreactivity in chemically defined target neurons of the hypothalamus. J. Neurosci., 18 (1998), 559-572

HAY, M.; MORMÈDE, P.:

Improved determination of urinary cortisol and cortisone, or corticosterone and 11dehydrocorticosterone by high-performance liquid chromatography with ultraviolet absorbance detection. J. Chromatogr. B. Biomed. Sci. Appl., 702 (1997), 33-39

HEILIG, M.; KOOB, G.F.; EKMAN, R.; BRITTON, K.T.:

Corticotropin-releasing factor and neuropeptide Y: role in emotional integration. Trends Neurosci., 17 (1994), 80-85

HEIMAN, M.L.; AHIMA, R.S.; CRAFT, L.S.; SCHORNER, B.; STEPHENS, T.W.; FLIER, J.S.: Leptin inhibition of the hypothalamic-pituitary-adrenal axis in response to stress. Endocrinology, 138 (1997), 3859-3863

HENRY, B.A.; GODING, J.W.; ALEXANDER, W.S.; TILBROOCK, A.J.; CANNY, B.J.; DUNSHEA, F.; RAO, A.; MANSELL, A.; CLARKE, I.J.:

Central administration of leptin to ovarectomized ewes inhibits food intake without affecting the secretion of hormones from the pituitary gland: evidence for a dissociation of effects on apppetite and neuroendocrine function. Endocrinology, 140 (1999), 1175-1182

HERBISON, A.E.:

Noradrenergic regulation of cyclic GnRH secretion. Rev. Reproduct., 2 (1997), 1-6

HERMAN, J.P; CULLINAN, W.E.:

Neurocircuitry of stress: central control of the hypothalamo-pituitary-adrenocortical axis. Trends Neurosci., 20 (1997), 78-84

HOLAHAN, M.R.; KALIN, N.H.; KELLEY, A.E.: 
Microinfusion of corticotropin-releasing factor into the nucleus accumbens shell results in increased behavioral arousal and oral motor activity. Psychopharmacology, 130 (1997), 189-196

HU, Z.; YURL, K.; MOROMOTO, M.; OZAWA, H.; KAWATA, M.:

Chronic loss of glucocorticoids following adrenalectomy down-regulates the expression of glucocorticoid receptor mRNA in the rat forebrain. Eur. J. Neurosci., 9 (1997), 1778-1783

INGVARTSEN, K.L.; BOISCLAIR, Y.R.:

Leptin and the regulation of food intake, energy homeostasis and immunity with special focus on INUI, A.: periparturient ruminants. Domest. Anim. Endocrinol., 21 (2001), 215-250

Feeding and body-weight regulation by hypothalamic neuropeptides - mediation of the actions of leptin. Trends Neurosci., 22 (1999), 62-67

INUI, A.:

Ghrelin: an orexiogenic and somatotrophic signal from the stomach. Nature Rev. Neurosci., 2 (2001), 551-560

ISAACSON, R.L.; GISPEN, W.H.:

Neuropeptides and the issue of stereotypy in behaviour. In: S.J. COOPER, C.T. DOURISH (eds.), Neurobiology of Stereotyped Behaviour, pp 118-141, Clarendon Press, Oxford 1990

JANSEN, A.S.; NGUYEN, X. V. ; KARPITSKIY, V. ; METTENLEITER, T. C.; LOEWY, A. D.:

Central command neurons of the sympathetic nervous system: basis of the flight-or-fight response. Science, 270 (1995), 644-646

JEANRENAUD, B.; ROHNER-JEANRENAUD, F.:

CNS-periphery relationships and body weight homeostasis: influence of the glucocorticoid status. Int. J.

JOELS, M.: Obes. Relat. Metab. Disord., Suppl.2 (2000), S74-S76

JOELS, M.:

Corticosteroid actions in hippocampus. J. Neuroendocrinol., 13 (2001), 657-669

Modulatory actions of steroid hormones on electrical activity in brain. Eur. J. Pharmacol., 405 (2000), 207-216

JOHNSON, E.O.; KAMILARIS, T.C.: CHROUSOS, G.P.; GOLD, P.W.:

Mechanisms of stress: a dynamic overview of hormoral and behavioral homeostasis. Neurosci. Biobehav. Rev., 16 (1992), 115-130

JONES, T.H.; KENNEDY, R.L.:

Cytokines and the hypothalamic-pituitary function. Cytokine, 5 (1993), 531-538

JORGENSEN, L.S.; BONLOKKE, L.; CHRISTENSEN, N.J.:

Plasma adrenaline and noradrenaline during mental stress and isometric exercise in man. The role of arterial sampling. J. Clin. Lab. Invest., 45 (1985), 447-452

KANITZ, E.; MANTEUFFEL, G.; OTTEN, W.:

Effects of weaning and restraint stress on glucocorticoid receptor binding capacity in limbic brain areas of domestic pigs. Brain Res., 804 (1998), 311-315

KANITZ, E.; OTTEN, W.; NÜRNBERG, G.; BRÜSSOW, K.P.:

Effects of age and maternal reactivity on the stress response of the pituitary-adrenocortical axis and the sympathetic nervous system in neonatal pigs. Anim. Sci., 68 (1999), 519-526

KANITZ, E.; TUCHSCHERER, M.; TUCHSCHERER, A.; STABENOW, B.; MANTEUFFEL, G.:

Neuroendocrine and immune responses to acute endotoxemia in suckling and weaned piglets. Biol. Neonate, 81 (2002), 203-209

KARALIS, K.; MUGLIA, L.J.; BAE, D.; HILDERBRAND, H.; MAJZOUB, J.A.: CRH and the immune system. J. Neuroimmunol., 72 (1997), 131-136

KARST, H.; KARTEN, Y.J.; REICHARDT, H.M.; DE KLOET, E.R.; SCHUTZ, G.; JOELS, M.: Corticosteroid actions in hippocampus require DANN binding of glucocorticoid receptor homodimers. Nat. Neurosci., 3 (2000), 977-978

KATZ, R.J.; CARROL, B.J.; BALDRIGHI, J.: Behavioural activation by enkephalins in mice. Parmacol., Biochem. Behav., 8 (1978), 493-496

KEENAN, D.M.; LICINIO, J.; VELDHUIS, J.D.:

A feedback-controlled ensemble model of the stress-responsive hypothalamo-pituitary-adrenal axis. Proc. Natl. Acad. Sci. USA, 98 (2001), 4028-4033

KIM, J.J.; DIAMOND, D.M.:

The stressed hippocampus, synaptic plasticity and lost memories. Nature Rev. Neurosci., 3 (2002), 453462

KIM, J.J.; YOON, K.S.:

Stress: metaplastic effects in the hippocampus. Trends Neurosci., 21 (1998), 505-509

KOOB, G.F.; HEINRICHS, S.C.; MERLO-PICH, E.; MENZAGHI, F.; BALDWIN, H.; MICZEK, K.; BRITTON, K.T.: 
The role of corticotropin-releasing factor in behavioural responses to stress. In: E.B. De SOUZA, C.B. NEMEROFF (eds.), Corticotropin-Releasing Factor: Basic and Clinical Studies of a Neuropeptide, pp 277-295, CRC Press, Boca Raton 1993

KOOLHAAS, J.M.; BAUMANS, V.; BLOM, H.J.M.:

Behavior, stress and well-being. In: L.F.M. VAN ZUTPHEN, V. BAUMANS, A.C. BEYEN (eds), Principles of laboratory animal science, pp 75-100, Elsevier, New York 1993

KORTE, S.M.:

Corticosteroids in relation to fear, anxiety and psychopathology. Neuroscience and Biobehavioral Rev., 25 (2001), 117-142

KRYSIAK, R.; OBUCHOWICZ, E.; HERMAN, Z.S.:

Interactions between the neuropeptide Y system and the hypothalamic-pituitary-adrenal axis. Eur. J. Endocrinol., 140 (1999), 130-136

KUSNECOV, A.V.; GROTA, L.J.; SCHMIDT, S.G.; BONNEAU, R.H.; SHERIDAN, J.F.; GLASER, R.; MOYNIHAN, J.A.:

Decreased herpes simplex viral immunity and enhanced pathogenesis following stressor administration in mice. J. Neuroimmunol., 38 (1992), 129-138

KUSNECOV, A.V.; RABIN, B.S.:

Stressor-induced alteration of immune function: mechanisms and issues. Int. Arch. Allergy Immunol., 105 (1994), 107-121

LADEWIG, J.:

Chronic intermittend stress: a model for the study of long-term stressors. In: G.P. MOBERG, J.A. MENCH (eds.), The Biology of Animal Stress, pp 159-169, CAB International, Wallingford, UK 2000

LADEWIG, J; DE PASSILLÉ, A.M.; SCHOUTEN, W.; TERLOUW, C.; VON BORELL, E.: Stress and the physiological correlates of stereotypic behaviour. In: A.B. LAWRENCE, J. RUSHEN (eds.), Stereotypic Animal Behaviour. Fundamentals and Application to Welfare. CAB International, Wellingford 1993

LIANG, K.C.: LEE, E.H.Y.: Intra-amygdala injections of corticotropin-releasing factor facilitate inhibitory avoidance learning and reduce exploratory behavior in rats. Psychopharmacology, 96 (1988), 232-236

LICINIO, J.; MANTZOROS, C.; NEGRÃO, A.B.; CIZZA, G.; WONG, M.L.; BONGIORNO, P.B.; CHROUSOS, G.P.; KARP, B.; ALLEN, C.; FLIER, J.S.; GOLD, P.W.:

Human leptin levels are pulsatile and inversely related to pituitary-adrenal function. Nat. Med., 3 (1997), 575-579

LIENAU, A.K.; KUSCHINSKY, K.:

Sensitization phenomena after repeated administration of cocaine or D-amphetamine in rats: associative and non-associative mechanisms and the role of dopamine in the striatum. Naunyn-Schmiedeberg's Arch. Pharmacol., 355 (1997), 531-537

LIGHTMAN, S.L.:

How does the hypothalamus respond to stress? Neurosciences, 6 (1994), 215-219

MACFARLANE, M.S.; BREEN, K.M.; SAKURAI, H.; ADAMS, B.M.; ADAMS, T.E.:

Effect of duration of infusion of stress-like concentrations of cortisol on follicular development and the preovulatory surge of LH in sheep. Anim. Reprod. Sci., 63 (2000), 167-175

MAKINO, S.; GOLD, P.W.; SCHULKIN, J.:

Effects of corticosterone on CRH mRNA and content in the bed nucleus of the stria terminalis; comparison with the effects in the central nucleus of the amygdala and the paraventricular nucleus of the hypothalamus. Brain Res., 657 (1994), 141-149

MANTEUFFEL, G.; PUPPE, B.:

Animal well-being in husbandry and coping with stress. Arch. Tierz. Dummerstorf, 43 (2000) Special Issue, 140-143

MANTEUFFEL, G.; PUPPE, B.:

Is it possible to judge the subjective perception of internal state in animals? A critical analysis from a scientific point of view. Arch. Tierz. Dummerstorf, 40 (1997), 109-121

MATTHEWS, S.G.:

Dynamic changes in glucocorticoid and mineralocorticoid receptor mRNA in the developing guinea pig brain. Dev. Brain Res., 107 (1998), 123-32

MC GREEVY, P.; NICOL, C.:

Physiological and behavioral consequences associated with short-term prevention of crib-biting in horses. Physiol. Behav., 65 (1998) 1, 15-23

MCEWEN, B.S.; BIRON, C.A.; BRUNSON, K.W.; BULLOCH, K.; CHAMBERS, W.H.; DHABHAR, F.S.;

GOLDFARB, R.H.; KITSON, R.P.; MILLER, A.H.; SPENCER, R.L.; WEISS, J.M.:

The role of adrenocorticoids as modulators of immune function in health and disease: neural, endocrine and immune interactions. Brain Res. Rev., 23 (1997), 79-133 
MEDINA, J.F.; REPA, J.C.; MAUK, M.D.; LEDOUX, J.E.:

Parallels between cerebellum- and amygdala-dependent conditioning. Nature Rev. Neurosci., 3 (2002), 122-131

MEYER, U.; KRUHOFFER, M.; FLUGGE, G.; FUCHS, E:

Cloning of glucocorticoid receptor and mineralocorticoid receptor cDNA and gene expression in the central nervous system of the tree shrew (Tupaia belangeri). Mol. Brain Res., 55 (1998), 243-53

MILLER, A.H.:

Neuroendocrine and immune system interactions in stress and depression. Psychoneuroendocrinology, 21 (1998), 443-463

MOBERG, G.P.:

Influence of stress on reproduction: measure of well-being. In: G.P. MOBERG (ed.), Animal Stress, pp 245-267, American Physiological Soc., Bethesda 1980

MUNCK, A.; GUYRE, P.M.:

Glucocorticoids and immune function. In: R. ADER, D.L. FELTEN, N. COHEN (eds.), Psychoneuroimmunology, pp 447-474, Academic Press, New York 1991

OKRASA, S.; KALAMARZ, H.: Involvement of the opioid system in the control of LH secretion in sows. Reprod. Dom. Anim., 31 (1996), 575-583

OLFF, M.:

Stress, depression and immunity: the role of defense and coping styles. Psychatry Res., 85 (1999) 7-13

OLIVERIO, A.; CASTELLANO, C.; PUGLISI-ALLEGRA, S.:

Psychobiology of opioids. Interntl. Rev. Neurobiol., 25 (1984), 277-337

OTTAVIANI, E.; FRANCHINI, A.; GENEDANI, S.:

ACTH and its role in immune-neuroendocrine functions. A comparative study. Current Pharmaceutical Design, 5 (1999), 673-681

OTTEN, W.; KANITZ, E.; TUCHSCHERER, M.; NÜRNBERG, G.:

Effects of prenatal restraint stress on hypothalamic-pituitary-adrenocortical and sympathoadrenomedullary axis in neonatal pigs. Anim. Sci., 73 (2001), 279-287

OTTEN, W.; PUPPE, B.; KANITZ, E.; SCHÖN, P.C.; STABENOW, B.:

Physiological and behavioral effects of different success during social confrontation in pigs with prior dominance experience. Physiol. Behav., 75 (2002), 127-133

PALKOVITZ, M.:

Organization of the stress response at the anatomical level. Prog. Brain Res., 27 (1987), 47-55

PARVIZI, N.; ELLENDORFF, F.:

Further evidence on dual effects of norepinephrine on LH secretion. Neuroendocrinology, 35 (1982), 48-55

PERREAU, V.; SARRIEAU, A.; MORMÈDE, P.:

Characterization of mineralocorticoid and glucocorticoid receptors in pigs: comparison of Meishan and Large White breeds. Life Sci., 64 (1999), 1501-1515

PETERS, M.L.; GODAERT, G.L.R.; BALLIEUX, R.E.; BROSSCHOT, J.F.; SWEEP, F.C.G.J.; SWINKELS,

L.M.J.W.; VAN VLIET, M.; HEIJNEN, C.J.:

Immune responses to experimental stress: effects of mental effort and uncontrollability. Psychosomatic Medicine, 61 (1999), 513-524

PITKÄNEN, A.; SAVANDER, V.; LEDOUX, J.E.:

Organization of intra-amygdaloid circuitries in the rat: an emerging framework for understanding functions of the amygdala. Trends Neurosci., 20 (1997), 517-523

POL, F.; COURBOULAY, V.; COTTE, J.P.; MARTRENCHAR, A.; HAY, M.; MORMÈDE, P.:

Urinary cortisol as an additional tool to assess the welfare of pregnant sows kept in two types of housing. Vet. Res., 33 (2002), 13-22

RABIN, D.; GOLD, P.W.; MARGIORIS, A.N.; CHROUSOS, G.P.:

Stress and reproduction: physiologic interactions between the stress and reproductive axes. In: G.P. CHRROUSOS, D.L. LORIAUX, P.W. GOLD (eds.), Mechanisms of Physical and Emotional Stress. Advances in Experimental Medicine and Biology Vol. 245: pp 377-387, Prentice-Hall, New York 1988

RAMOS, A.; MORMÈDE, P.:

Stress and emotionality: a multidimensional and genetic approach. Neuroscience and Biobehav. Rev., REDBO, I.: 22 (1998), 33-57

Relations between oral stereotypies, open-field behavior, and pituitary-adrenal system in growing dairy cattle. Physiol. Behav., 64 (1998) 3, 273-278

REUL, J.M.H.M.; VAN DEN BOSCH, F.R.; DE KLOET, E.R.:

Differential response of type 1 and type 2 corticosteroid receptors to changes in plasma steroid level and circadian rythmicity. Neuroendocrinology, 45 (1987), 407-412 
RIVEST, S.; RIVIER, C.:

Central mechanisms and sites of action involved in the inhibitory effects of CRF and cytokines on LHRH neuronal activity. In: Y. TACHÉ, C. RIVIER (eds.), Corticotropin-Releasing Factor and Cytokines: Role in the Stress Response, pp 117-141, N.Y. Acad. Sci., New York 1993

RIVIER, C.; CHIZZONITE, R.; VALE, W.:

In the mouse, the activation of hypothalamic-pituitary adrenal axis by a lipopolysaccharide (endotoxin) is mediated through interleukin-1. Endocrinology, 125 (1989), 2800-2805

RIVIER, C.; RIVEST, S.:

Effect of stress on the activity of the hypothalamic-pituitary-gonadal axis: peripheral and central mechanisms. Biol. Reproduction, 45 (1991), 523-532

ROSENBLUM, L.A.:

Influences of environmental demand on maternal behavior and infant development. In: N.A. KRASNEGOR, E.M. BLASS, M.A. HOFER, W.P. SMOTHERMAN (eds.), Perinatal Development: A Psychobiological Perspective, pp 377-395, Academic Press, New York 1987

RUCKEBUSCH, Y.; MALBERT, C.H.:

Stimulation, and inhibition of food intake in sheep by centrally-administered hypothalamic releasing factors. Life Sci., 38 (1986), 929-934

SAGE, D.; MAUREL, D.; BOSLER, O.:

Corticosterone-dependent driving influence of the suprachiasmatic nucleus on adrenal sensitivity to ACTH. Am. J. Physiol. Endocrinol. Metab., 282 (2002), E458-465

SAKAKURA, N.; TAKEBE, K.; NAKAGAWA, S.:

Inhibition of luteinizing hormone secretion induced by synthetic LRH by long-term treatment with glucocorticoids in human subjects. J. Clin. Endocrinol. Metabol., 40 (1975), 774-779

SALAK-JOHNSON, J.L.; MCGLONE, J.J.; WHISNANT, C.S.; NORMAN, R.L.; KRAELING, R.R.:

Intracerebroventricular porcine corticotropin-releasing hormone and cortisol effects on pig immune measures and behavior. Physiol. Behav., 61 (1997), 15-23

SAPOLSKY, R.M.; ROMERO, L.M.; MUNCK, A.U.:

How do glucocorticoids influence stress responses? Integrating permissive, suppressive, stimulatory, and preparative actions. Endocrine Rev., 21 (2000), 55-89

SAVORYA, C.J.; MANNA, J.S.:

Is There a Role for Corticosterone in Expression of Abnormal Behaviour in Restricted-Fed Fowls? Physiol. Behav., 62 (1997) 1, 7-13

SCHNEIKERT, J.; HUBNER, S.; LANGER, G.; PETRI, T.; JAATTELA, M.; REED, J.; CATO, A.C.:

Hsp70-RAP46 interaction in downregulation of DANN binding by glucocorticoid receptor. EMBO J., 19 (2000), 6508-6516

SCHÖN, P.C.; PUPPE, B.; MANTEUFFEL, G.:

Linear prediction coding analysis and self-organizing feature map as tools to classify stress calls of domestic pigs (Sus scrofa). J. Acoust. Soc. Am., 110 (2001), 1425-1432

SCHÖNREITER, S.; ZANELLA, A.J.:

Assessment of cortisol in swine by saliva: a new methodological approach. Arch. Tierz., Dummerstorf 43 (2000) Special Issue, 165-170

SCHOUTEN, W.; LENSINK, J.; LAKWIJK, N.; WIEGANT, V.M.:

De-arousal effect of stereotypies in tethered sows. Proceedings of the $34^{\text {th }}$ International Congress of the ISAE, Florianapolis, Brasil. (2000) p 46

SCHOUTEN, W.; RUSHEN, J.; DE PASILLÉ, A.M.:

Stereotypic behaviour and heart rate in pigs. Physiol. Behav., 50 (1991), 617-624

SCHWARTZ, M.W.; WOODS, S.C.; PORTE, D.; SEELEY, R.J.; BASKIN, D.J.:

SELYE, H.: Central nervous system control of food intake. Nature, 404 (2000), 661-671

SELYE, H.:

A syndrome produced by diverse nocous agents. Nature, 138 (1936), 32

The general adaptation syndrome and the diseases of adaptation. J. Clin. Endocrinol., 6 (1946), 117-230

SLIEKER, L.J.; SLOOP, K.W.; SURFACE, P.L.; KRIAUCIUNAS, A.; LA QUIER, F.; MANETTA, J.:

Regulation of expression of $o b$ mRNA and protein by glucocorticoids and cAMP. J. Biol. Chem., 271 (1996), 5301-5304

STARKMAN, M.N.; GIODANI, B.; GEBARSKI, S.S.; BERENT, S.; SCHORK, M.A.; SCHTEINGART, D.E.: Decrease in cortisol reverses human hippocampal atrophy following treatment of Cushing's disease. Biol. Psychiatry, 46 (1999), 1595-1602

STODDARD, S.L.; BERGDALL, V.K.; TOWNSEND, D.W.; LEVIN, B.E.:

Plasma catecholamines associated with hypothalamically-elicited defense behavior. Physiol. Behav., 36 (1986), 867-873

SUTANO, W.; ROSENFELD, P.; DE KLOET, E.R.; LEVINE, S.: 
Long-term effects of neonatal maternal deprivation and ACTH on hippocampal mineralocorticoid and glucocorticoid receptors. Dev. Brain Res., 92 (1996), 156-163

SVENSON, T.H.:

Peripheral, autonomic regulation of locus coeruleus noradrenergic neurons in brain: putative implications for psychiatry and psychopharmacology. Psychopharmacology, 92 (1992), 1-7

SYLVESTER, P.W.; VAN VUGT, D.A.; AYLSWORTH, C.A.; HANSEN, E.A.; MEITES, J.:

Effects of morphine and naloxone on inhibition by ovarian hormones of pulsatile release of $\mathrm{LH}$ in ovarectomized rats. Neuroendocrinology, 34 (1982), 269-273

THIÉRY, J.-C.; MARTIN, G.B.:

Neurophysiological control of the secretion of gonadotrophin-releasing hormone and luteinizing hormone in the sheep - a review. Reprod. Fertil. Dev., 3 (1991), 137-173

THORSELL, A.; SVENSSON, P.; WIKLUND, L.; SOMMER, W.; EKMAN, R.; HEILIG, M.:

Suppressed neuropeptide Y (NPY) mRNA in rat amygdala following restraint stress. Regulatory Peptides, 75-76 (1998), 247-254

TUCHSCHERER, M.; KANITZ, E.; OTTEN, W.; TUCHSCHERER, A.:

Effects of prenatal stress on cellular and humoral immune responses in neonatal pigs. Vet. Immunology Immunopathol., 86 (2002), 195-203

TUCHSCHERER, M.; MANTEUFFEL, G.:

Die Wirkung von psychischem Stress auf das Immunsystem. Ein weiterer Grund für tiergerechte Haltung. Arch. Tierz., Dummerstorf 43 (2000), 547-560

TUCHSCHERER, M.; PUPPE, B.; TUCHSCHERER, A.; KANITZ, E.:

Effects of social status after mixing on immune, metaboloic, and endocrine responses in pigs. Physiol. Behav., 64 (1998), 353-360

UEHARA, Y.; SHIMIZU, H.; OHTANI, K.; SATO, N.; MORI, M.:

Hypothalamic corticotropin-releasing hormone is a mediator of anorexigenic effect of leptin. Diabetes, 47 (1998), 890-893

VALENTINO, R.J.; FOOTE, S.L.; PAGE, M.E.:

The locus coeruleus as a site for integrating corticotropin-releasing factor and noradrenergic mediation of stress responses. In: Y. TACHÉ, C. RIVIER (eds.), Corticotropin-Releasing Factor and Cytokines: Role in the Stress Response, pp 173-188, N.Y. Acad. Sci., New York 1993

VAN HAARST, A.D.; OITZL, M.S.; DE KLOET, E.R.:

Faciltitation of feedback inhibition through blockade of glucocorticoid receptors in the hippocampus. Neurochem. Res., 22 (1997), 1323-1328

VÁZQUEZ, D.M.; VAN OERS, H.; LEVINE, S.; AKIL, H.:

Regulation of glucocorticoid and mineralocorticoid receptor mRNAs in the hippocampus of maternally deprived infant rat. Brain Res., 731 (1996),79-90

VELDHUIS, J.D.; IRANMANESH, A.; NAFTOLOWITZ, D.; TATHAM, N.; CASSIDY, F.; CARROLL, B.J.: Corticotropin secretory dynamics in humans under low glucocorticoid feedback. J. Clin. Endocrinol. Metabol., 86 (2001),5554-5563

VERNON, R.G.; DENIS, R.G.P.; SØRENSEN, A.: Signals of adiposity. Domest. Anim. Endocrinol., 21 (2001), 197-214

VON BORELL, E.: Stress and coping in farm animals. Arch. Tierz., Dummerstorf 43 (2000) Special Issue, 144-152

WANG, H.L.; WAYNER, M.J.; CHAI, C.Y.; LEE, E.H.Y.:

Corticotrophin-releasing factor produces a long-lasting enhancement of synaptic efficacy in the hippocampus. Eur. J. Neurosci., 10 (1998), 3428-3437

WEIDENFELD, J.; ITZIK, A.; FELDMAN, S.:

Effect of glucocorticoids on the adreneocortical axis responses to electrical stimulation of the amygdala and the ventral noradrenergic bundle. Brain Res., 754 (1997), 187-194

WEITZMAN, E.D.; FUKUSHIMA, D.; NOGEIRE, C.; ROFFWARG, H.; GALLAGHER, T.F.: HELLMAN, L.:

Twenty-four hour pattern of the episodic secretion of cortisol in normal subjects. J. Clin. Endocrinol. Metab., 33 (1971), 14-22

WELBERG, L.A.; SECKL, J.R.:

Prenatal stress, glucocorticoids and the programming of the brain. J. Neuroendocrinol., 13 (2001), 113128

WELBERG, L.A.; SECKL, J.R.; HOLMES, M.C.:

Inhibition of 11beta-hydroxysteroid dehydrogenase, the foeto-placental barrier to maternal glucocorticoids, permanently programs amygdala GR mRNA expression and anxiety-like behaviour in the offspring. Eur. J. Neurosci., 12 (2000), 1047-1054

WELSH, T.H.; BAMBINO, T.H.; HSUEH, A.J.W.: 
Mechanism of glucocorticoid-induced suppression of testicular androgen biosynthesis in vitro. Biol. Reprod., 27 (1982), 1138-1146

WHITNALL, MH.:

Regulation of the hypothalamic corticotropin-releasing hormone neurosecretory system. Prog. Neurobiol., 40 (1993), 573-629

WILLIAMS, L.M.; ADAM, C.L.; MERCER, J.G.; MOAR, K.M.; SLATER, D.; HUNTER, L.; FINDLAY, P.A.; HOGGARD, N.:

Leptin receptor and neuropeptide Y gene expression in the sheep brain. J. Neuroendocrinol., 11 (1999), 165-169

YEN, S.S.C.:

Chronic anovulation caused by peripheral endocrine disorders. In: S.S.C. YEN, R.B. JAFFE (eds.), Reproductive Endocrinology. Physiology, Pathophysiology and Clinical Management, pp 441-499, Saunders Co, Philadelphia 1986

YOUNG, E.A.; VAZQUEZ, D.:

Hypercortisolemia, hippocampal glucocorticoid receptors, and fast feedback. Mol. Psychatry, 1 (1996), 149-159

ZAKON, H.H.:

The effects of steroid hormones on electrical activity of excitable cells. Trends Neurosci., 21 (1998), 202-207

ZANELLA, A.J.; BROOM, D.M.; HUNTER, J.C.; MENDL, M.T.:

Brain opioid receptors in relation to stereotypies, inactivity, and housing in sows. Physiol. Behav. 59 (1996), 769-775

Received: 2002-08-01

Accepted: 2002-09-20

Author's address

Prof. Dr. GERHARD MANTEUFFEL

FBN Dummerstorf

Res. Unit Behavioral Physiology

Wilhelm-Stahl-Allee 2

D-18196 Dummerstorf

Germany 